\title{
FERTILIZATION OF RAT EGGS IN VITRO AT VARIOUS TIMES BEFORE AND AFTER OVULATION WITH SPECIAL REFERENCE TO FERTILIZATION OF OVARIAN OOCYTES MATURED IN CULTURE
}

\author{
K. NIWA* AND M. G. CHANG \\ Worcester Foundation for Experimental Biology, \\ Shrewsbury, Massachusetts 01545, U.S.A.
}

(Received 8th October 1974)

\begin{abstract}
Summary. Oocytes recovered at various times from immature rats treated with PMSG and HCG were incubated with capacitated epididymal spermatozoa of mature rats. In the presence of follicular cells, sperm penetration was not observed $4 \mathrm{hr}$ after incubation in the oocytes at stages from the intact germinal vesicle to the chromatin mass, but 7 to $55 \%$ of oocytes were penetrated at stages from the condensed germinal vesicle to metaphase II. After the removal of follicular cells, 15 to $72 \%$ of the oocytes at any stage were penetrated. After further incubation for $15 \mathrm{hr}$, the proportion of penetrated oocytes increased from 8 to $98 \%$ from early to late stages and that of penetrated oocytes with a male and female pronucleus increased from 9 to $100 \%$ as maturation progressed. Although the average number of spermatozoa/oocyte was not correlated with its maturation, transformation of the sperm head into a male pronucleus was retarded or failed, especially in the younger oocytes. Following incubation in a defined medium for $13 \mathrm{hr}$, $85 \%$ of oocytes at the intact germinal vesicle stage matured to the stage of the first polar body formation, but only 18 to $22 \%$ of these mature oocytes were penetrated by spermatozoa and only a few of the penetrated oocytes cleaved into normal two-cell eggs. When eggs recovered from oviducts 14 to $20 \mathrm{hr}$ after ovulation were exposed to capacitated spermatozoa, the proportion of penetrated eggs ( 86 to $98 \%$ ) and that of polyspermic eggs (11 to $27 \%$ ) were not related to the ages of the eggs, but failure of transformation of the sperm head and the proportion of abnormal eggs increased 14 to $20 \mathrm{hr}$ after ovulation.
\end{abstract}

\section{INTRODUGTION}

Fertilization and development of ovarian oocytes following their transfer after the first maturation division into mated animals was reported in rats (Noyes, 1952) and rabbits (Chang, 1955a, b; Motlik \& Fulka, 1974). Recently, the possibility of fertilization of ovarian oocytes in vitro has been described for man

\footnotetext{
* Present address: Department of Animal Science, College of Agriculture, Kyoto University, Kyoto, Japan 606 .
} 
(Edwards, Bavister \& Steptoe, 1969; Seitz, Rocha, Brackett \& Mastroianni, 1971; Soupart \& Morgenstern, 1973), rabbits (Brackett, Mills \& Jeitles, 1972; Thibault, 1973), mice (Cross \& Brinster, 1970; Iwamatsu \& Chang, 1971, 1972) and guinea-pigs (Yanagimachi, 1974). So far as we are aware, there has been no study on the possibility of fertilization in vitro of rat oocytes at various times before ovulation.

Successful fertilization of rat eggs in vitro by spermatozoa recovered from the uterus (Miyamoto \& Chang, 1973a, b) and by epididymal spermatozoa in a defined medium (Toyoda \& Chang, 1974a, b) has been reported, and various conditions for the capacitation of rat spermatozoa and the fertilization of rat eggs in vitro have been defined (Niwa \& Chang, 1973, 1974a, b, c). Since the eggs recovered from immature rats after superovulation can be fertilized in vitro more easily than those from mature rats (Niwa \& Chang, 1973), and since rat epididymal spermatozoa are more effectively capacitated by preincubation in a diluted than in a concentrated form (Niwa \& Chang, 1974a), these new techniques have made it possible to investigate more easily and accurately the morphology and physiology of the fertilization of rat eggs. The present study was designed to determine the possibility of fertilization in vitro of rat ovarian oocytes at various stages during maturation, fertilization of rat oocytes matured in culture, and the fertilization in vitro of rat eggs at various times after ovulation.

\section{MATERIALS AND METHODS}

White rats of the CD strain descended from Sprague-Dawley rats were used. Immature female rats ( 22 to 24 days old) were induced to superovulate by a subcutaneous injection of 10 i.u. PMSG 40 to $50 \mathrm{hr}$ before an intraperitoneal injection of 10 i.u. HCG. Thirty to fifty eggs/animal were obtained in this strain of rat. Spermatozoa were obtained from the cauda epididymidis of adult rats (330 to 360 days old) according to the procedure reported elsewhere (Niwa \& Chang, 1973; Toyoda \& Chang, 1974a). A small drop of the dense sperm mass was first introduced into $0.5 \mathrm{ml}$ medium covered with warm paraffin oil (Saybolt, viscosity 125/135: Fisher Scientific Co.) in a tissue culture dish $(35 \times 10 \mathrm{~mm}$ : Falcon Plastics). The paraffin oil was previously equilibrated with $5 \% \mathrm{CO}_{2}$ in air. About $10 \mathrm{~min}$ after making this sperm suspension, $0.03 \mathrm{ml}$ was placed in $0.4 \mathrm{ml}$ of the same medium covered with paraffin oil. This diluted sperm suspension $\left(0.4\right.$ to $1.3 \times 10^{6}$ spermatozoa $\left./ \mathrm{ml}\right)$ was preincubated for 5 to $6 \mathrm{hr}$ in a $\mathrm{CO}_{2}$ incubator $\left(5 \% \mathrm{CO}_{2}\right.$ in air at $37^{\circ} \mathrm{C}$ ) (Niwa \& Chang, 1974a). The composition and the method of preparation of the medium were the same as described by Toyoda \& Chang (1974a).

For the collection of oocytes, immature females were killed at various times after injection of HCG. Their ovaries were removed, cleared from adhering blood on a piece of filter paper, placed in the medium without bovine serum albumin but containing $0.1 \%$ hyaluronidase (from bovine testes, type I: Sigma Chemical Co.), and covered with oil. Large follicles were broken by means of sharp needles under a dissecting microscope for recovery of the oocytes. After 30 to $60 \mathrm{~min}$, the recovered oocytes were washed twice in the same medium without hyaluronidase and examined to determine their stage of 
maturation or were introduced into the sperm suspension. The stages of maturation were arbitrarily classified according to the photographs and the descriptions of mouse oocytes by Donahue (1968). In Exp. 1, the stages of oocytes recovered at various times after injection of HCG were estimated. In Exp. 2, oocytes treated with hyaluronidase but still partly surrounded with follicular cells were washed twice and introduced to a preincubated sperm suspension. In Exp. 3, the follicular cells attached to the oocytes in $0.1 \%$ hyaluronidase were completely removed by sucking the oocytes in and out through a small-bore pipette. The oocytes were then washed twice and introduced into the preincubated sperm suspension. The oocytes in these two experiments were examined $4 \mathrm{hr}$ after exposure to spermatozoa. In Exp. 4, the oocytes, after complete removal of follicular cells, as in the case of Exp. 3, were exposed to preincubated spermatozoa. Four hr after insemination, they were washed, transferred into $0.4 \mathrm{ml}$ newly prepared medium and incubated for another $15 \mathrm{hr}$. The oocytes were then examined to ascertain their nuclear configuration and the degree of transformation of the sperm head.

For the study of maturation of oocytes in culture and their subsequent fertilization in vitro, oocytes with an intact germinal vesicle were obtained from the ovary of immature rats injected $48 \mathrm{hr}$ previously with $10 \mathrm{i} . u$. PMSG. The oocytes were collected in $0.4 \mathrm{ml}$ medium containing $0.1 \%$ hyaluronidase, washed twice in $0.5 \mathrm{ml}$ medium without hyaluronidase, and were introduced into another dish containing $0.4 \mathrm{ml}$ medium with bovine serum albumin. After culture for $13 \mathrm{hr}$, ten oocytes from each rat were examined for the stages of maturation and the remainder were exposed to preincubated spermatozoa. They were then examined 12 or $24 \mathrm{hr}$ later for evidence of sperm penetration and fertilization.

To study the fertilization in vitro of eggs at various times after ovulation, the females were killed 16 to $32 \frac{1}{2} \mathrm{hr}$ after injection of HCG. Ovulation usually occurred $12 \mathrm{hr}$ after injection of HCG. Eggs recovered in a cumulus clot from the ampullary portion of the oviducts were introduced into the preincubated sperm suspension. After incubation for $21 \frac{1}{2}$ to $22 \frac{3}{4} \mathrm{hr}$, the eggs were examined for evidence of sperm penetration and fertilization. The relationship between the developmental stages of penetrated eggs and polyspermic eggs was also examined.

Throughout these studies, the oocytes or eggs were mounted in toto, and were then fixed and stained with $0.25 \%$ lacmoid in $45 \%$ acetic acid (Chang, 1952). They were examined to determine their stage of maturation and for evidence of sperm penetration and fertilization. The term 'penetrated' was used of all oocytes or eggs with spermatozoa in their cytoplasm or in their perivitelline space. Oocytes or eggs containing one or more enlarged sperm heads, or pronuclei or which had cleaved and contained a fertilizing sperm tail(s) in the vitellus were considered to be undergoing fertilization or to be fertilized.

\section{RESULTS}

Experiment 1. Stages of maturation in oocytes recovered at various times before ovulation As shown in Table 1, practically all the oocytes recovered 0 to $4 \mathrm{hr}$ after 


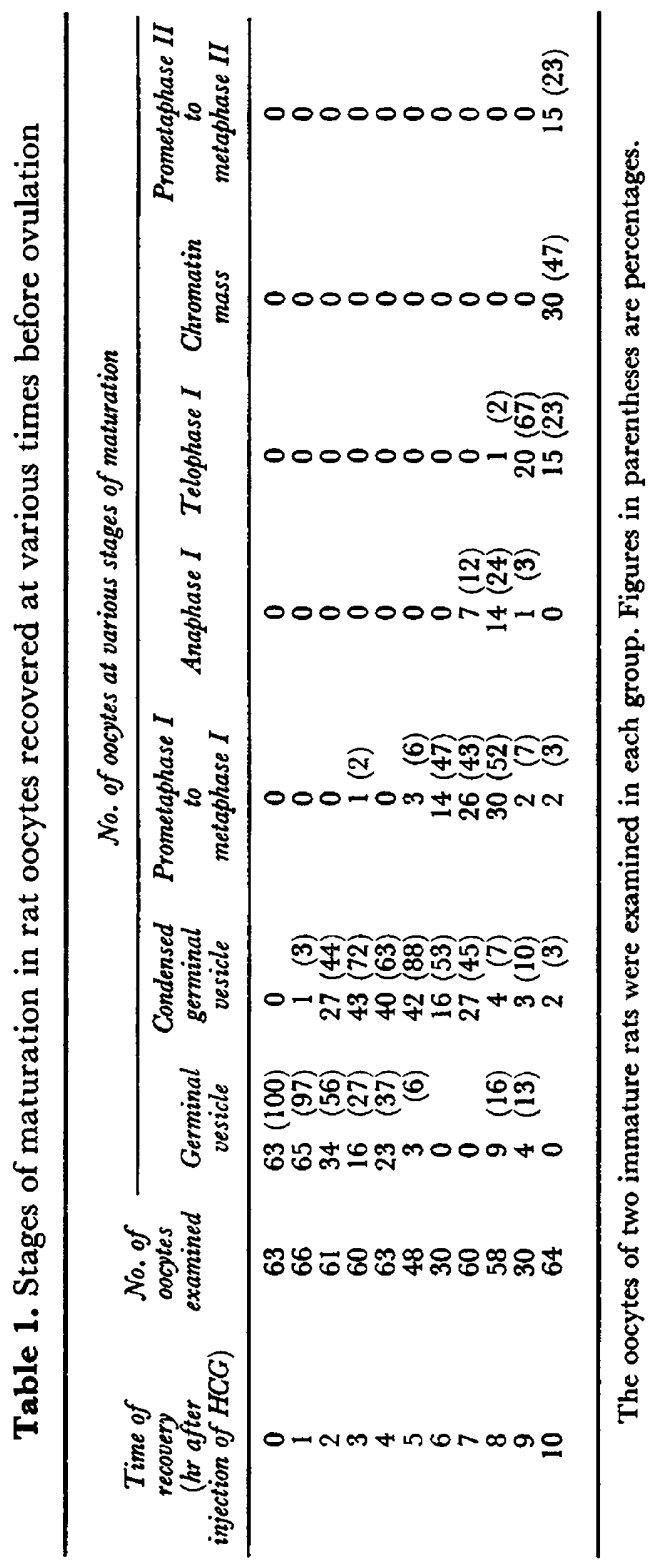


injection of HCG had an intact or a condensed germinal vesicle, but the breakdown of the germinal vesicle had begun from $1 \mathrm{hr}$ after injection of HCG and increased to $88 \% 5 \mathrm{hr}$ later. Although the first prometaphase I had appeared $3 \mathrm{hr}$ after injection of HCG, 43 to $52 \%$ of oocytes recovered 6 to $8 \mathrm{hr}$ after injection of HCG were at prometaphase I or metaphase I. Anaphase I, telophase I and the chromatin mass appeared, respectively, 7, 8 and $10 \mathrm{hr}$ after injection of HCG. Ten hr after the injection of HCG, thirty $(47 \%)$ of sixty-four oocytes were at the chromatin mass stage and fifteen $(23 \%)$ were at prophase II to metaphase II, but all oocytes at chromatin mass to metaphase II had extruded their first polar body.

Experiment 2. Sperm penetration at various stages of maturation in the oocytes with follicular cells

As shown in Table 2, of 331 oocytes exposed to preincubated spermatozoa 0 to $4 \mathrm{hr}$ after injection of HCG, only one was penetrated, while 7 to $55 \%$ of

Table 2. Sperm penetration in vitro at various stages of maturation of rat oocytes

\begin{tabular}{|c|c|c|c|c|c|c|}
\hline \multirow{2}{*}{$\begin{array}{l}\text { Stages of maturation } \\
\text { at examination }\end{array}$} & \multicolumn{6}{|c|}{$\begin{array}{c}\text { No. of penetrated oocytes (including no. of oocytes with enlarged } \\
\text { sperm head)/no. of oocytes exposed to spermatozoa at various times } \\
\text { after injection of } H C G\end{array}$} \\
\hline & $0 \mathrm{hr}$ & $2 \mathrm{hr}$ & $4 \mathrm{hr}$ & $6 \mathrm{hr}$ & $8 \mathrm{hr}$ & $10 \mathrm{hr}$ \\
\hline $\begin{array}{l}\text { Germinal vesicle } \\
\text { Gondensed germinal vesicle } \\
\text { Prometaphase I to metaphase I } \\
\text { Anaphase I } \\
\text { Telophase I } \\
\text { Ghromatin mass } \\
\text { Metaphase II } \\
\text { Anaphase II } \\
\text { Telophase II } \\
\text { Chromatin mass }\end{array}$ & $\begin{array}{c}0 / 7 \\
0 / 90 \\
1(0) 20 \\
= \\
= \\
= \\
=\end{array}$ & $\begin{array}{l}0 / 5 \\
0 / 41 \\
0 / 52 \\
= \\
= \\
= \\
=\end{array}$ & $\begin{array}{l}0 / 8 \\
0 / 29 \\
0 / 49 \\
0 / 5 \\
0 / 15 \\
0 / 10 \\
= \\
=\end{array}$ & $\begin{array}{c}0 / 8 \\
1(1) / 17 \\
3(1) / 29 \\
2(0) / 17 \\
1(1) / 25 \\
1(1) / 15 \\
0 / 5 \\
= \\
=\end{array}$ & $\begin{array}{c}0 / 5 \\
0 / 14 \\
0 / 19 \\
0 / 6 \\
3(3) / 8 \\
34(32) / 34 \\
3(3) / 16 \\
4(4) / 4 \\
2(2) / 2\end{array}$ & $\begin{array}{c}0 / 2 \\
0 / 9 \\
0 / 12 \\
0 / 2 \\
0 / 4 \\
5(5) / 17 \\
17(17) / 23 \\
5(5) / 5 \\
12(12) / 12 \\
22(22) / 24\end{array}$ \\
\hline Total & $\begin{array}{c}1(0) / 117 \\
(1 \%)\end{array}$ & $\begin{array}{l}0 / 98 \\
\left(0^{\circ} \%\right)\end{array}$ & $\begin{array}{l}0 / 116 \\
\left(0^{\circ} \%\right)\end{array}$ & $\begin{array}{c}8(4) / 116 \\
(7 \%)\end{array}$ & $\begin{array}{c}46(44) / 108 \\
(43 \%)\end{array}$ & $\begin{array}{c}61(61) / 110 \\
(55 \%)\end{array}$ \\
\hline
\end{tabular}

Oocytes collected at various times after injection of HGG were exposed to epididymal spermatozoa preincubated at a concentration of 0.4 to $0.9 \times 10^{6}$ spermatozoa $/ \mathrm{ml}$ for $5 \frac{1}{2}$ to $6 \mathrm{hr}$ and were examined $4 \mathrm{hr}$ after exposure. Follicular cells were still attached to a high proportion of the oocytes when they were introduced into the sperm suspension.

oocytes 6 to $10 \mathrm{hr}$ after injection of HCG were penetrated $4 \mathrm{hr}$ after being introduced into the sperm suspension. Of these penetrated oocytes, 50 to $100 \%$ had an enlarged sperm head in the vitellus (PI. 1, Fig. 1) but in the short incubation time, not one of the enlarged heads had transformed into a male pronucleus.

Experiment 3. Sperm penetration at various stages of maturation in the oocytes without follicular cells

From the results presented in Table 3, it can be seen that although the oocytes at earlier stages of maturation could be penetrated (15 to $42 \%$ ) after the removal of follicular cells, the proportion of oocytes penetrated was higher (43 to $72 \%$ ) in the oocytes exposed to spermatozoa at later stages of maturation. The 
proportions of oocytes containing enlarged sperm head(s) were much higher in the oocytes exposed to spermatozoa 6 to $10 \mathrm{hr}$ after injection of HCG (96 to $100 \%$ ) than in those exposed 0 to $4 \mathrm{hr}$ after injection of HCG (11 to $38 \%$ ). It seems that the possibility of sperm penetration (Pl. 1, Fig. 2) was better in the absence than in the presence of follicular cells (Tables 2 and 3). In almost all oocytes undergoing fertilization, regardless of their maturation stage at the time of their exposure to spermatozoa, the sperm head was swollen but had not

Table 3. Sperm penetration in vitro at various stages of maturation in rat oocytes without follicular cells

\begin{tabular}{|c|c|c|c|c|c|c|}
\hline \multirow{2}{*}{$\begin{array}{l}\text { Stages of maturation } \\
\text { at examination }\end{array}$} & \multicolumn{6}{|c|}{$\begin{array}{c}\text { No. of penetrated oocytes (including no. of oocytes with enlarged } \\
\text { sperm head)/no. of oocytes exposed to spermatozoa at various times } \\
\text { after injection of HCG }\end{array}$} \\
\hline & $0 \mathrm{hr}$ & $2 h r$ & $4 h r$ & $6 h r$ & $8 h r$ & $10 \mathrm{hr}$ \\
\hline $\begin{array}{l}\text { Germinal vesicle } \\
\text { Condensed germinal vesicle } \\
\text { Prometaphase I to metaphase I } \\
\text { Anaphase I } \\
\text { Telophase I } \\
\text { Chromatin mass } \\
\text { Metaphase II } \\
\text { Anaphase II } \\
\text { Telophase II } \\
\text { Chromatin mass }\end{array}$ & $\begin{array}{l}1(0) / 2 \\
12(3) / 25 \\
10(2) / 31 \\
- \\
2(1) * / 2 \\
- \\
- \\
-\end{array}$ & $\begin{array}{l}2(0) / 4 \\
1(0) / 24 \\
5(1) / 30 \\
0 / 1 \\
= \\
- \\
- \\
-\end{array}$ & $\begin{array}{c}1(0) / 2 \\
2(0) / 35 \\
10(5) / 23 \\
= \\
- \\
- \\
- \\
-\end{array}$ & $\begin{array}{c}0 / 2 \\
0 / 1 \\
2(2) / 4 \\
2(2) / 4 \\
3(3) / 5 \\
33(33) / 41 \\
0 / 1 \\
= \\
-\end{array}$ & $\begin{array}{c}\overline{-} \\
\overline{-} \\
2 \overline{(2) / 2} \\
18(18) / 21 \\
5(5) / 36 \\
1(0) / 1 \\
- \\
-\end{array}$ & $\begin{array}{c}\overline{-} \\
1(\overline{1}) / 3 \\
1(1) / 3 \\
\overline{1(1) / 1} \\
5(5) / 12 \\
0 / 1 \\
2(2) / 5 \\
33(33) / 35\end{array}$ \\
\hline Total & $\begin{array}{c}25(5) / 60 \\
(42 \%)\end{array}$ & $\begin{array}{c}9(1) / 60 \\
(15 \%)\end{array}$ & $\begin{array}{c}13(5) / 60 \\
(22 \%)\end{array}$ & $\begin{array}{c}40(40) / 60 \\
(67 \%)\end{array}$ & $\begin{array}{c}26(25) / 60 \\
(43 \%)\end{array}$ & $\begin{array}{c}43(43) / 60 \\
(72 \%)\end{array}$ \\
\hline
\end{tabular}

The follicular cells of ovarian oocytes collected at various times after injection of HCG were removed by treatment with $0.1 \%$ hyaluronidase. The oocytes were exposed to epididymal spermatozoa preincubated at a concentration of 0.5 to $1.3 \times 10^{6}$ spermatozoa/ml for 5 to $6 \mathrm{hr}$ and were examined $4 \mathrm{hr}$ after exposure.

* This oocyte had a polar body and female chromatin with two male pronuclei and two fertilizing sperm tails.

transformed into a pronucleus (see Pl. 1, Fig. 1). Only one oocyte exposed without injection of HCG had two pronuclei with two fertilizing sperm tails and a female chromatin mass with a polar body (Pl. 1, Fig. 3). The progression of nuclear maturation of oocytes incubated with spermatozoa for $4 \mathrm{hr}$ (Tables 2 and 3) was almost the same as in vivo (Table 1).

\section{Experiment 4. Morphology of oocytes inseminated at various times before ovulation after prolonged culture}

Since the transformation of an enlarged sperm head into a male pronucleus was not observed $4 \mathrm{hr}$ after incubation (Tables 2 and 3), the incubation was continued for a longer time. The results presented in Table 4 show that oocytes penetrated within $4 \mathrm{hr}$ after incubation with spermatozoa were capable of undergoing fertilization after incubation for a further $15 \mathrm{hr}$. But the proportion of oocytes with two normal pronuclei, one female and one male with corresponding sperm tail (see Pl. 1, Fig. 4), was higher in those oocytes exposed to spermatozoa 6 to $10 \mathrm{hr}$ after injection of HCG (60 to $100 \%$ ) than in those exposed at earlier times ( 9 to $40 \%$ ). High proportions of the latter showed some 


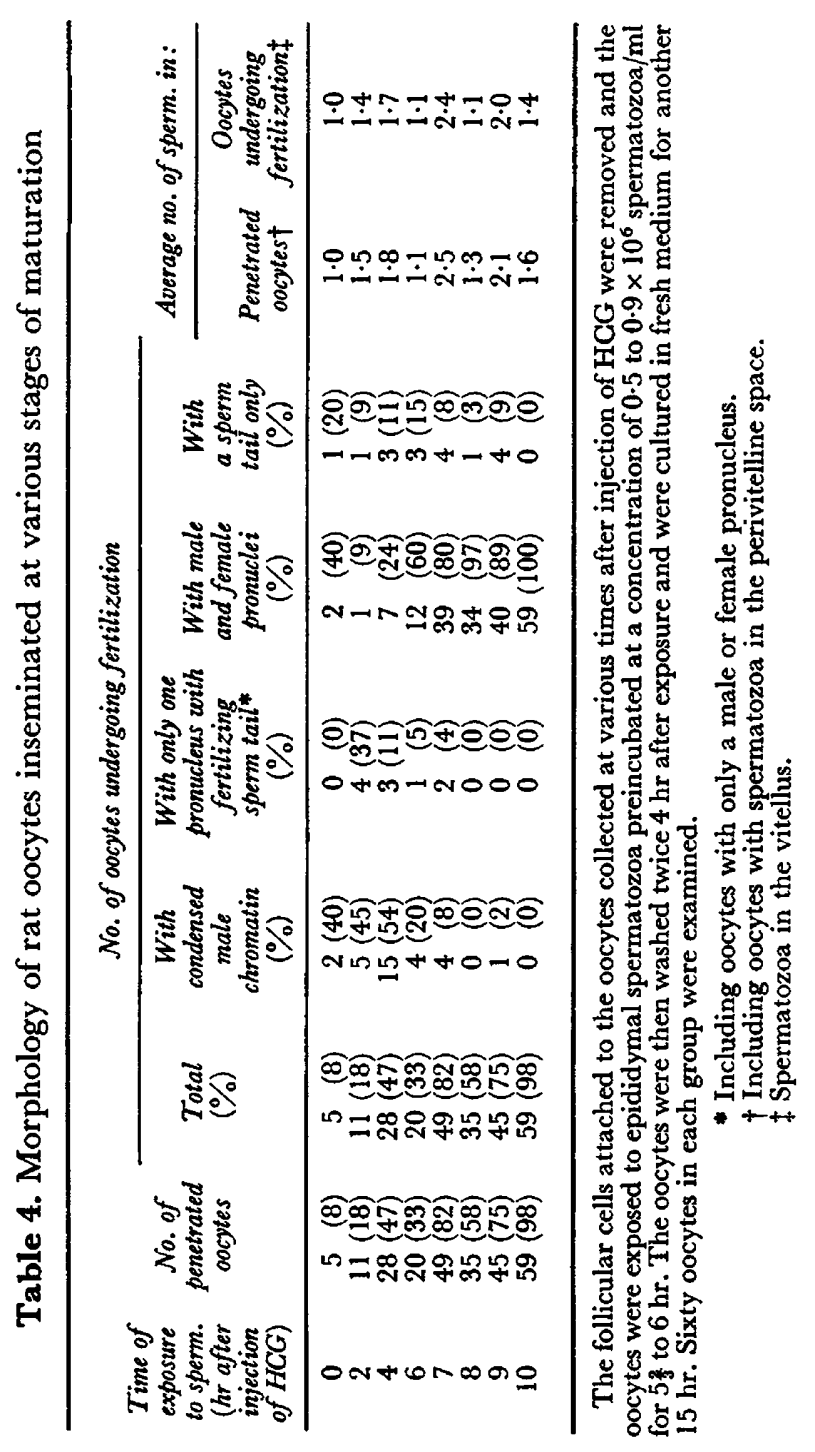


abnormality during the transformation of the sperm head. For instance, the sperm head was a condensed mass of chromatin (Pl. 1, Fig. 5) or presented the appearance of a 'spindle' (Pl. 1, Fig. 6). Some oocytes had a small pronucleus with fertilizing sperm tail (PI. 1, Fig. 7). By contrast, fifty-nine $(98 \%$ ) of sixty oocytes exposed to spermatozoa $10 \mathrm{hr}$ after injection of HCG were undergoing fertilization and all of them had normal male and female pronuclei.

To determine whether oocytes undergoing fertilization could accomplish the final stage of fertilization, twenty-five oocytes exposed to spermatozoa $10 \mathrm{hr}$ after injection of HCG were transferred into fresh medium $4 \mathrm{hr}$ later. When these oocytes were examined $32 \mathrm{hr}$ after further incubation, twenty-four $(96 \%)$ were at the pronuclear stage and nineteen $(76 \%)$ of them were at the two-cell stage (Pl. 1, Fig. 8).

The efficiency of the zona pellucida in blocking further entry of spermatozoa during oocyte maturation was examined by counting the number of spermatozoa inside each penetrated oocyte. As shown in Table 4, the average number of spermatozoa in the penetrated oocytes was 1.0 to 2.5 , and there was no correlation between the stage of oocyte maturation and the number of spermatozoa that had penetrated. Similarly, the number of spermatozoa in the polyspermic eggs was not affected by the age of the eggs (Table 4).

\section{EXPLANATION OF PLATE 1}

All the rat oocytes were photographed after being stained with lacmoid under a phasecontrast microscope with a $\times 10$ ocular and $\times 40$ objective. All magnifications $\times 250$ to 350 .

Fig. 1. An oocyte recovered from the ovary $10 \mathrm{hr}$ after injection of HCG, exposed to capacitated epididymal spermatozoa in the presence of follicular cells and examined $4 \mathrm{hr}$ later. It had an enlarged sperm head (SH), fertilizing sperm tail, the second polar body (p2) and female condensed chromatin (FCC). The first polar body is out of focus.

FIG. 2. An oocyte recovered without injection of HCG, exposed to spermatozoa in the absence of follicular cells and examined $4 \mathrm{hr}$ later. It had a condensed germinal vesicle (GGV) with two spermatozoa in the perivitelline space. The sperm heads (arrows) are still intact.

FiG. 3. An oocyte recovered without injection of $H C G$, exposed to spermatozoa in the absence of follicular cells and examined $4 \mathrm{hr}$ later. It had two possible male pronuclei (MP) and two fertilizing sperm tails (arrows). The polar bodies and condensed female chromatin are out of focus.

FIG. 4. An oocyte recovered $4 \mathrm{hr}$ after injection of $\mathrm{HCG}$, exposed to spermatozoa in the absence of follicular cells for $4 \mathrm{hr}$ and cultured for another $15 \mathrm{hr}$. It had two male pronuclei with two fertilizing sperm tails (arrows). The second polar body and the female pronucleus are out of focus.

F1G. 5. An oocyte recovered without injection of HCG, exposed to spermatozoa in the absence of follicular cells for $4 \mathrm{hr}$ and cultured for another $15 \mathrm{hr}$. It had small fragments of the cytoplasm and the sperm head (arrow) was condensed but had failed to form a pronucleus.

FIG. 6. An oocyte recovered $4 \mathrm{hr}$ after injection of $\mathrm{HGG}$, exposed to spermatozoa in the absence of follicular cells for $4 \mathrm{hr}$ and cultured for another $15 \mathrm{hr}$. The sperm head (arrow) looked like a spindle and its tail is out of focus (arrows).

Fig. 7. An oocyte recovered $4 \mathrm{hr}$ after injection of HGG, exposed to spermatozoa in the absence of follicular cells for $4 \mathrm{hr}$ and cultured for another $15 \mathrm{hr}$. It had condensed female chromatin (FCG) and a sperm tail (arrow) but no sperm head.

Fig. 8. An oocyte recovered $10 \mathrm{hr}$ after injection of HCG, exposed to spermatozoa in the absence of follicular cells for $4 \mathrm{hr}$ and cultured for another $32 \mathrm{hr}$. It cleaved normally with the second polar body (p2) and a fertilizing tail (arrow).

Fig. 9. An oocyte recovered without injection of HCG. It was cultured for $13 \mathrm{hr}$, exposed to capacitated epididymal sperma tozoa and examined $12 \mathrm{hr}$ later. It had a male pronucleus (MP) slightly out of focus, with sperm tail (arrow), and a female pronucleus (FP). The second polar body is out of focus. 


\section{Nuclear maturation of rat oocytes cultured in a defined medium}

In order to determine whether oocytes with an intact germinal vesicle could complete their nuclear maturation after a longer time of culture, the oocytes obtained from immature rats injected with 10 i.u. PMSG $48 \mathrm{hr}$ previously were

\section{Table 5. Nuclear maturation of rat oocytes cultured in a defined medium}

\begin{tabular}{cc}
\hline Test & $\begin{array}{c}\text { No. of oocytes with } \\
\text { first polar body/no. of } \\
\text { oocytes examined }(\%)\end{array}$ \\
no. & $13 / 20(65)$ \\
1 & $20 / 20(100)$ \\
2 & $18 / 20(90)$ \\
3 & $17 / 20(85)$ \\
4 & $68 / 80(85)$ \\
Total & \\
\hline
\end{tabular}

Oocytes obtained from immature rats ( 26 days old) $48 \mathrm{hr}$ after injection of 10 i.u. PMSG were recovered in 0.4 $\mathrm{ml}$ medium containing $0.1 \%$ hyaluronidase, washed twice in $0.5 \mathrm{ml}$ medium without hyaluronidase, and then cultured in $0.4 \mathrm{ml}$ medium. Eggs from two immature rats were cultured in each test. Follicular cells were not completely removed. About forty-five oocytes from one female were cultured in a separate dish, but only ten were examined $13 \mathrm{hr}$ after culture.

\section{EXPLANATION OF PLATE 2}

All the rat oocytes or eggs were photographed after being stained with lacmoid under a phase-contrast microscope with a $\times 10$ ocular and $\times 40$ objective. All magnifications $\times 250$ to 350 .

Frg. 10. An oocyte matured in culture, exposed to capacitated epididymal spermatozoa and examined $24 \mathrm{hr}$ later. It had a condensed chromatin (GC) but the sperm head (arrow) failed to form a male pronucleus.

Fig. 11. An oocyte matured in culture, exposed to spermatozoa and examined $24 \mathrm{hr}$ later, showing the metaphase of the first cleavage division, with fertilizing sperm tail (arrow) and some fragments of the cytoplasm.

Fig. 12. An oocyte matured in culture, exposed to spermatozoa and examined $24 \mathrm{hr}$ later. This oocyte cleaved normally with a fertilizing sperm tail and polar bodies.

Frg. 13. An oocyte matured in culture, exposed to spermatozoa and examined $24 \mathrm{hr}$ later. showing uneven cleavage with dispersed nuclei.

Fig. 14. An egg recovered from the oviduct $10 \mathrm{hr}$ after ovulation, inseminated with capacitated epididymal spermatozoa, and examined $22 \mathrm{hr}$ later. Showing the metaphase of the first cleavage (M) with a fertilizing sperm tail (arrow).

FIG. 15. A normally cleaved egg. It was recovered from the oviduct $10 \mathrm{hr}$ after ovulation, exposed to spermatozoa and cultured for $22 \mathrm{hr}$. The fertilizing sperm tail (arrow) and the second polar body (p2) are visible. The nuclei of both blastomeres are at the same stage. Fig. 16. A fragmented egg. It was recovered from the oviduct $20 \mathrm{hr}$ after ovulation, exposed to spermatozoa and examined $22 \mathrm{hr}$ later. A fertilizing sperm tail (arrow) is visible.

Fig. 17. An egg with dispersed nuclei. It was recovered $20 \mathrm{hr}$ after ovulation, exposed to spermatozoa and examined $22 \mathrm{hr}$ later. The fertilizing sperm tail (arrow) is out of focus. Frg. 18. A cleaved egg with asynchronized nuclei. This egg was recovered $20 \mathrm{hr}$ after ovulation, exposed to spermatozoa and examined $22 \mathrm{hr}$ later. 
cultured for $13 \mathrm{hr}$. From the results presented in Table 5, it can be seen that a very high proportion of oocytes (65 to $100 \%$ ) was at metaphase II or the chromatin mass stage with the first polar body. This shows that nuclear maturation from the germinal vesicle stage to division of the first polar body could be completed in a defined medium.

\section{Fertilization in vitro of rat oocytes matured in culture}

To determine whether the oocytes matured in culture could be penetrated and fertilized in vitro, the oocytes cultured for $13 \mathrm{hr}$ were exposed to preincubated spermatozoa. After incubation for $12 \mathrm{hr}$, twenty-six (22\%) out of 120 oocytes were penetrated and twenty-four $(92 \%)$ were undergoing fertilization (Table 6). Of those undergoing fertilization, twenty-two (92\%) had normal male and female pronuclei (Pl. 1, Fig. 9), one (4\%) had only a male pronucleus and one $(4 \%)$ had an enlarged sperm head.

When the oocytes were examined $24 \mathrm{hr}$ after exposure to spermatozoa, $18 \%$ of 120 oocytes were penetrated and all of them were undergoing fertilization. Of the twenty-one oocytes undergoing fertilization, nine $(43 \%)$ had male and female pronuclei, six $(29 \%)$ had only a male pronucleus, one $(5 \%)$ had an enlarged sperm head (PI. 2, Fig. 10), and five (23\%) were either at the metaphase of the first cleavage (Pl. 2, Fig. 11), or at the two-cell stage (Pl. 2, Figs 12 and 13). Of the four cleaved eggs, only two $(10 \%)$ were morphologically normal (e.g. Pl. 2, Fig. 12).

\section{Fertilization in vitro of rat eggs at various times after ovulation}

The eggs recovered from oviducts at various times after injection of HCG were exposed to preincubated epididymal spermatozoa and examined $21 \frac{1}{2}$ to $22 \frac{3}{4} \mathrm{hr}$ later. The eggs recovered 16 to $18 \frac{1}{2} \mathrm{hr}$ after injection of HCG were surrounded by compact cumulus oophorus. Those recovered 20 to $22 \frac{1}{2} \mathrm{hr}$ after injection of HCG were in a loose cumulus and a high proportion of eggs recovered 24 to $32 \frac{1}{2} \mathrm{hr}$ after injection of HCG were free from cumulus. The results in Table 7 show that very high proportions of eggs (86 to $98 \%$ ) recovered 16 to $32 \frac{1}{2} \mathrm{hr}$ after injection of HCG were penetrated. The proportions of eggs undergoing normal fertilization were high ( 81 to $91 \%$ ) when they were exposed to spermatozoa 4 to $12 \mathrm{hr}$ after ovulation (16 to $24 \frac{1}{2} \mathrm{hr}$ after injection of HCG), but decreased sharply ( 2 to $11 \%$ ) when they were exposed 16 to $20 \mathrm{hr}$ after ovulation. Similarly, the proportion of fragmented or abnormal eggs after sperm penetration was also markedly increased when the eggs were exposed 16 to $20 \frac{1}{2} \mathrm{hr}$ after ovulation (Table 7). The eggs undergoing normal fertilization or fertilized $21 \frac{1}{2}$ to $22 \frac{3}{4} \mathrm{hr}$ after exposure to spermatozoa were at the pronuclear stage, at various stages of first cleavage (Pl. 2, Fig. 14) or at the two-cell stage (Pl. 2, Fig. 15). Many of the eggs undergoing fertilization or fertilized when exposed to spermatozoa 14 to $20 \mathrm{hr}$ after ovulation were either fragmented (Pl. 2, Fig. 16) or had fragments. Some had dispersed pronuclei (Pl. 2, Fig. 17) or asynchronized nuclei at the two-cell stage (P1. 2, Fig. 18). As in the case of fertilization of early oocytes or after culture, transformation of a sperm head into a male pronucleus failed in many eggs inseminated $16 \mathrm{hr}$ after ovulation.

The proportions of total eggs penetrated by more than one spermatozoon 
PIATTli I

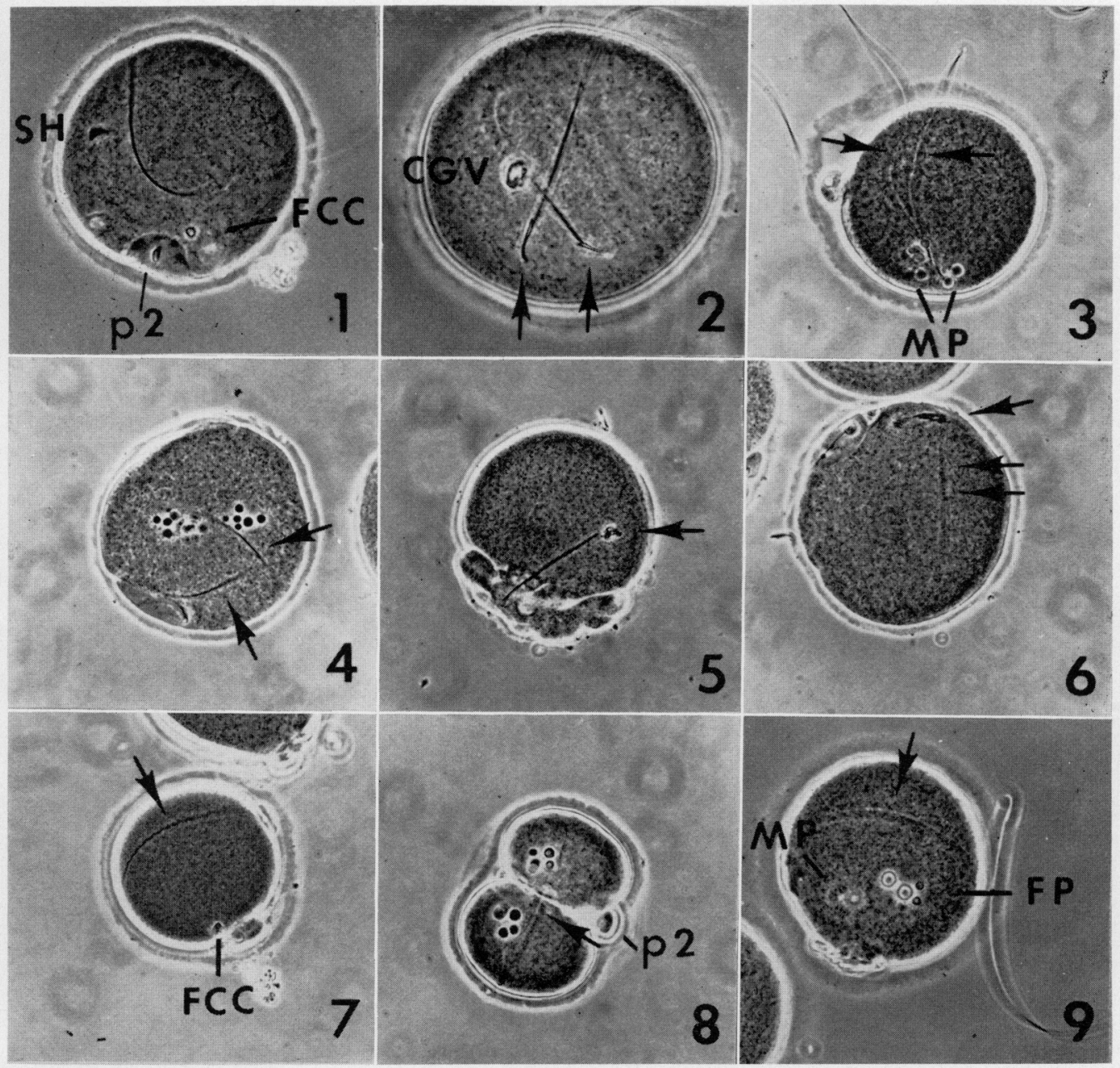

(Facing /. +42) 


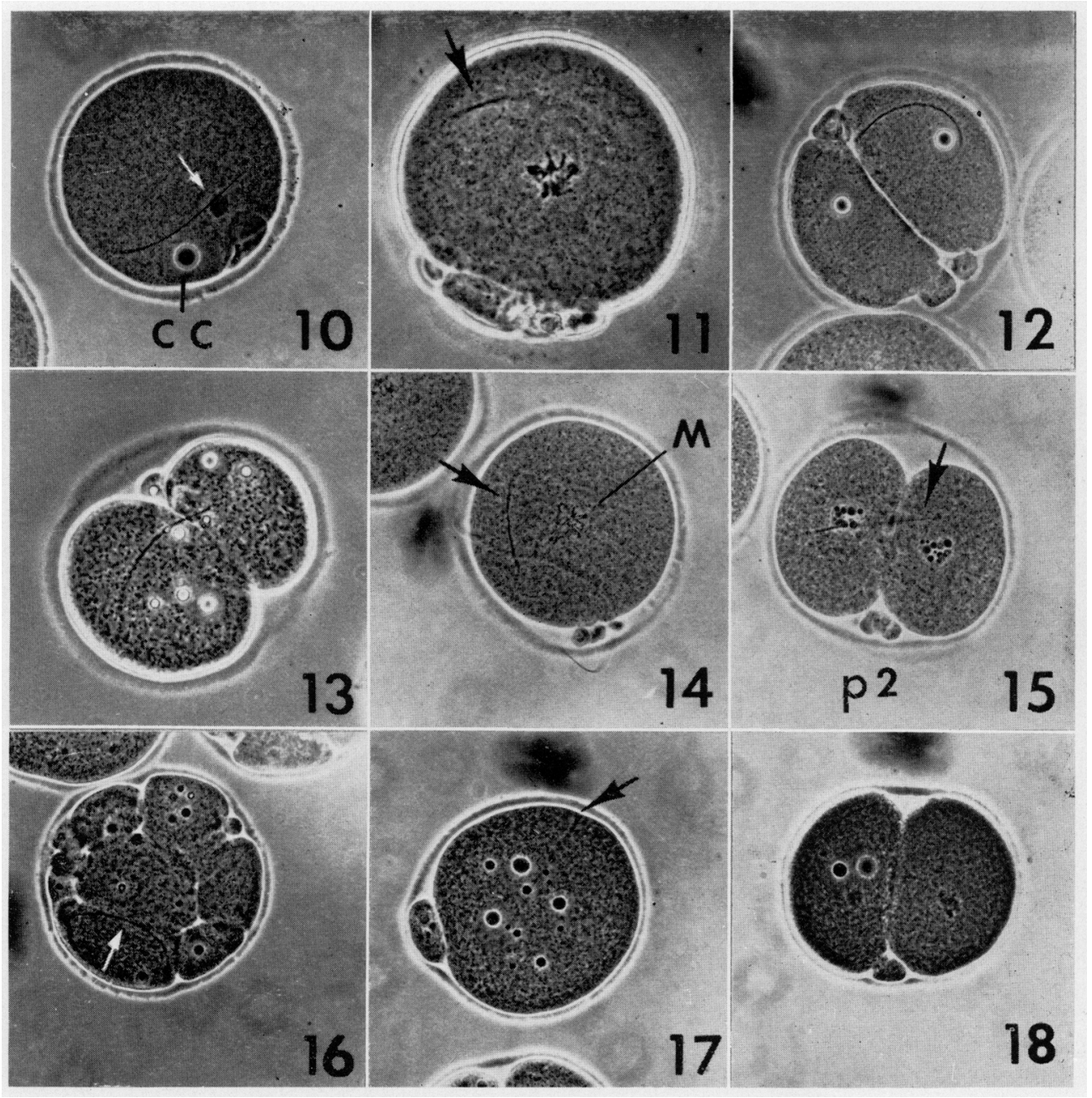




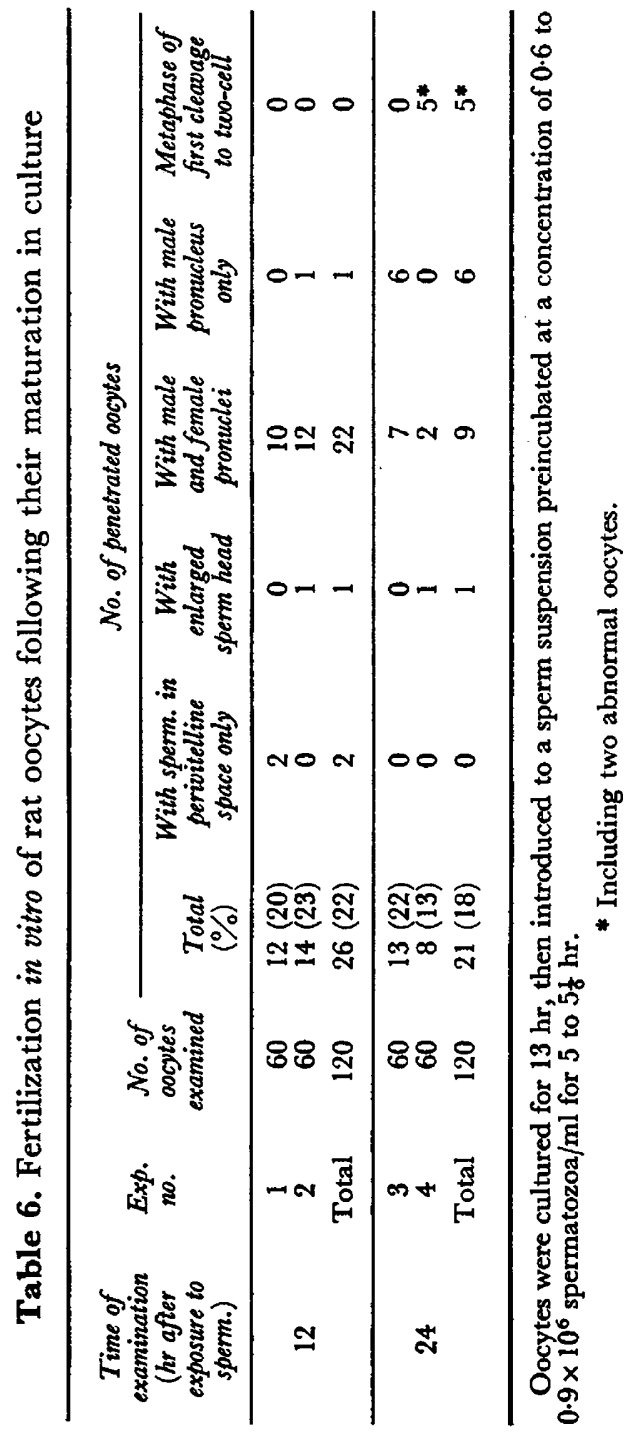


(14 to $54 \%$ ) and those of polyspermic eggs ( 11 to $27 \%$ ) were not related to the ages of eggs (Table 8). The number of abnormal eggs during fertilization, however, definitely increased when the eggs were introduced into the sperm suspension $12 \mathrm{hr}$ after ovulation. Regardless of the ages of eggs when they were introduced, the proportion of total eggs penetrated by more than one spermatozoon was $48 \%$ of 226 eggs at the pronuclear stage, $29 \%$ of 316 eggs at prophase to telophase of the first cleavage, and 14\% of 107 eggs at the two-cell stage. Furthermore, $48 \%$ of 330 eggs which were penetrated by more than one spermatozoon were abnormal during fertilization.

Table 7. Fertilization in vitro of rat eggs at various times after ovulation

\begin{tabular}{ccccc}
\hline $\begin{array}{c}\text { Time of exposure to sperm. } \\
\text { (hr after injection of HCG) }\end{array}$ & $\begin{array}{c}\text { No. of } \\
\text { eggs } \\
\text { examined }\end{array}$ & $\begin{array}{c}\text { No. of eggs } \\
\text { penetrated* } \\
(\%)\end{array}$ & $\begin{array}{c}\text { No. of eggs } \\
\text { undergoing normal } \\
\text { fertilization or } \\
\text { fertilized (\%) }\end{array}$ & $\begin{array}{c}\text { No. of } \\
\text { penetrated eggs } \\
\text { but fragmented } \\
\text { or abnormal }(\%) \dagger\end{array}$ \\
\hline 16 to $16 \frac{1}{2}$ & 114 & $99(87)$ & $99(87)$ & $0(0)$ \\
18 to $18 \frac{1}{2}$ & 72 & $66(92)$ & $62(86)$ & $4(6)$ \\
20 to $20 \frac{1}{2}$ & 112 & $107(96)$ & $102(91)$ & $5(5)$ \\
22 to $22 \frac{1}{2}$ & 194 & $166(86)$ & $162(84)$ & $4(2)$ \\
24 to $24 \frac{1}{2}$ & 144 & $141(98)$ & $116(81)$ & $25(18)$ \\
26 to $26 \frac{1}{2}$ & 124 & $108(87)$ & $82(66)$ & $26(24)$ \\
28 to $28 \frac{1}{2}$ & 142 & $136(96)$ & $12(8)$ & $124(91)$ \\
30 to $30 \frac{1}{2}$ & 118 & $103(87)$ & $13(11)$ & $90(87)$ \\
32 to $32 \frac{1}{2}$ & 60 & $53(88)$ & $1(2)$ & $52(98)$
\end{tabular}

Eggs were examined $21 \frac{1}{2}$ to $22 \frac{3}{4} \mathrm{hr}$ after exposure to epididymal spermatozoa preincubated at a concentration of 0.6 to $1.0 \times 10^{6}$ spermatozoa $/ \mathrm{ml}$ for 5 to $5 \frac{1}{2} \mathrm{hr}$. Eggs obtained from two to four immature rats after superovulation were used for each test.

* Including eggs with spermatozoa in perivitelline space.

$\uparrow$ Percentage of the total number of penetrated eggs.

\section{DISCUSSION}

In the mouse, sperm penetration in vitro was possible in the oocytes at any stage of maturation, but their fertilizability increased just before, or at the time of, completion of the first maturation division (Iwamatsu \& Chang, 1972). In the present study, it was observed that practically no oocytes were penetrated when they had an intact or condensed germinal vesicle if the follicular cells attached to the oocytes were not completely removed. When the follicular cells were removed, a high proportion of oocytes at these stages were penetrated in vitro. Since, in both cases, the penetration rates were higher when oocytes at later stages of maturation were exposed to spermatozoa, the fertilizability of rat oocytes appears to resemble that of mouse oocytes in this respect.

Although the beneficial effect of cumulus cells on the maturation of oocytes in culture has been reported for human (Kennedy \& Donahue, 1969), rabbit, cow (Robertson \& Baker, 1969) and mouse (Cross \& Brinster, 1970) eggs, there is evidence that this may be dependent upon the energy sources used (Biggers, Whittingham \& Donahue, 1967). In the present study, rat oocytes matured in culture regardless of the presence or absence of follicular cells. This may have been due to the presence of pyruvate in the medium (Biggers et al., 1967) and cumulus cells have been reported to produce pyruvate from 


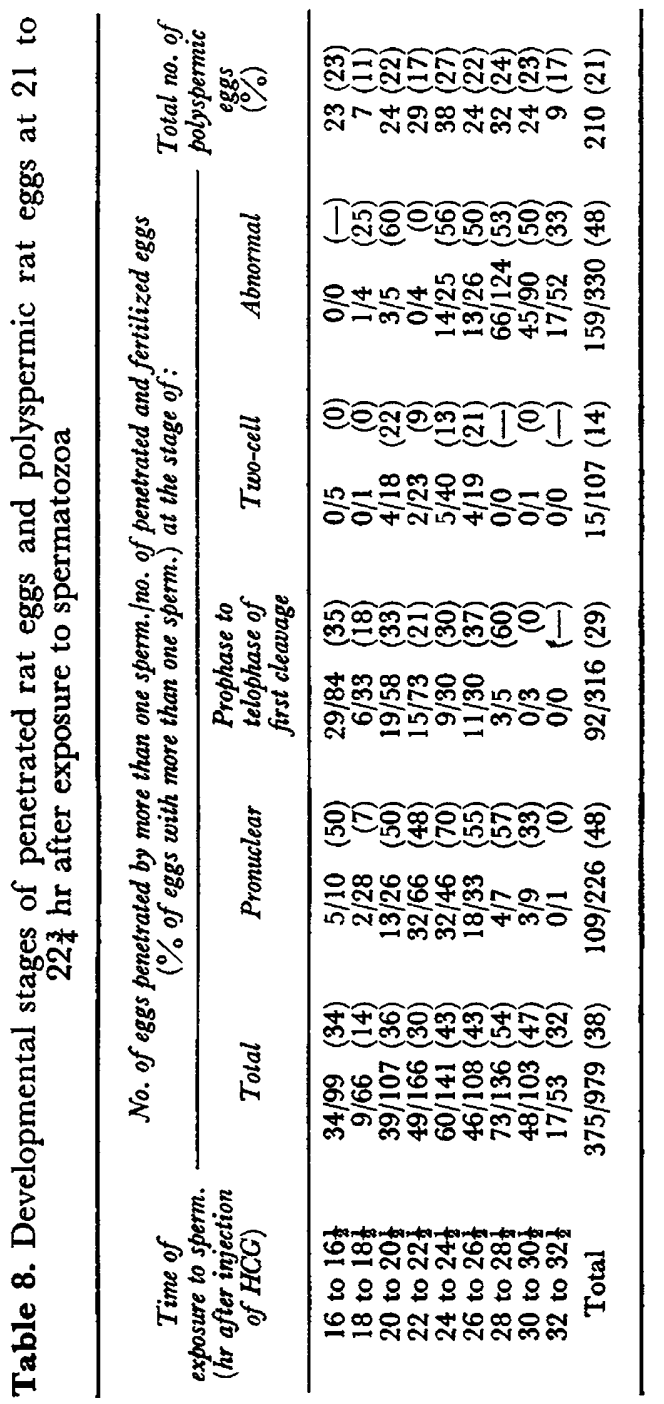


other substrates in vitro (Donahue \& Stern, 1968). Sperm penetration rates in the oocytes were lower in the presence than in the absence of follicular cells (Tables 2 and 3), but we are not sure whether the effect of follicular cells on the sperm penetration was due to a physical hindrance or due to chemical reactions.

It has been reported that when rat eggs were exposed in vitro to preincubated epididymal spermatozoa and examined $4 \mathrm{hr}$ later, twenty-three $(56 \%)$ of forty-one penetrated eggs were at the pronuclear stage (Niwa \& Chang, 1974a). In the present experiment, however, almost all oocytes at $4 \mathrm{hr}$ after exposure to spermatozoa had an enlarged sperm head without a male pronucleus, regardless of their stage of maturation and the presence or absence of follicular cells. When the oocytes were incubated for a further $15 \mathrm{hr}$, the proportions of oocytes with normal male and female pronuclei were relatively lower in younger oocytes than in older ones. It thus appears that the transformation of a sperm head into a male pronucleus is definitely hindered and delayed in the younger oocytes. A failure of decondensation of the sperm head in early hamster oocytes was reported by Yanagimachi \& Usui (1972) and we have observed a definite delay in the transformation of the sperm head in early rat oocytes.

It has been suggested that cytoplasmic maturation takes place after incorporation of the germinal vesicle material with the cytoplasm of the oocyte in other species (see Monroy \& Tyler, 1967). In the present experiment, some oocytes with intact germinal vesicle were penetrated but the sperm head was not incorporated into the vitellus and failed to transform into a pronucleus. This suggests that, without the incorporation of germinal vesicle material, the cytoplasm had no capacity to incorporate the sperm head for its transformation. A similar occurrence was observed in the rat primary oocytes in vivo (see Austin, 1961) and in mouse oocytes in vitro (Iwamatsu \& Chang, 1972). After breakdown of the germinal vesicle, sperm penetration and fertilization was possible but the proportion of oocytes penetrated, undergoing fertilization and with normal male and female pronuclei increased gradually from the condensed germinal vesicle stage to metaphase II. This indicates that the maturation of ooplasm as a whole is of importance for normal fertilization, although the degree of nuclear maturation is a good indication of the maturation of the eggs (Chang, 1955a).

The ability of the zona pellucida to block further sperm entry appeared to be weaker in mouse oocytes at certain stages before ovulation (Iwamatsu \& Chang, 1971, 1972). This was not confirmed in the present study because the average number of spermatozoa in the penetrated rat oocytes was not related to their stage of maturation at the time of exposure to spermatozoa (Table 4). This may have been due to the low concentration of spermatozoa. We have also observed that rat oocytes introduced into a sperm suspension $2 \mathrm{hr}$ before ovulation could accomplish the final stage of fertilization and cleaved into morphologically normal two-cell eggs.

Since the early demonstration that rabbit oocytes recovered from the ovary could mature in culture (Pincus \& Enzmann, 1935; Chang, 1955a, b), this has been confirmed in many species (Schuetz, 1969; Donahue, 1972; Biggers, 1973). In the present study, oocytes with an intact germinal vesicle were able to mature to the stage of first polar body formation in a defined medium. 
Fertilization after maturation in vitro has been observed in the oocytes of rabbits (Thibault, 1973), mice (Cross \& Brinster, 1970) and guinea-pigs (Yanagimachi, 1974), but the proportion of such eggs which developed normally after being transferred into recipients was only $3 \%$ in the mouse (Cross \& Brinster, 1970). In the present study, only 18 to $22 \%$ of oocytes matured in culture were penetrated (Table 6), which was remarkably low compared to the number of oocytes matured in the ovary (Tables 2 and 3 ) or of ovulated eggs recovered from the oviducts soon after ovulation (Table 7). Only two $(10 \%)$ of the twenty-one penetrated oocytes developed into normal two-cell eggs in culture (Table 6). Such low penetration and development rates can be explained by the improper maturation of oocytes in the medium or by the effect of manipulation in vitro as suggested by Thibault (1973).

Delay and abnormal transformation of the sperm head into a pronucleus in oocytes matured in culture has been attributed to lack of or insufficient synthesis of a 'male pronucleus growth factor' in rabbit (Thibault, 1973) and guinea-pig (Yanagimachi, 1974) oocytes. Under our experimental conditions, a very high proportion of rat oocytes matured in culture had normal pronuclei $12 \mathrm{hr}$ after exposure to spermatozoa, though the exact time of transformation of the sperm head was not determined.

By counting the offspring, it was reported that the extreme limit of the fertilizable life of rat eggs was about $12 \mathrm{hr}$ after ovulation (Blandau \& Jordan, 1941). By counting the fertilized eggs, Chang, Niwa \& Hunt (1975) found that 8 to $15 \%$ of eggs from mature rats and 1 to $16 \%$ of eggs from immature rats could be fertilized when the females were inseminated 8 to $9 \mathrm{hr}$ after ovulation. In the present experiment, the eggs recovered 4 to $20 \mathrm{hr}$ after ovulation could be penetrated in vitro, but the proportion of such eggs that could develop into normal two-cell-eggs decreased sharply $14 \mathrm{hr}$ after ovulation (Table 8). Since fully capacitated spermatozoa following preincubation were used in the present study, it appears that the time of sperm capacitation in vivo, especially long after ovulation, may have made a difference in the determination of the fertilizability of aged eggs.

When female rats were inseminated 9 to $12 \mathrm{hr}$ after ovulation, various abnormalities were observed during fertilization (Blandau, 1952; Chang et al., 1974). Abnormalities were also observed in the present study, especially when early oocytes, cultured oocytes, or aged eggs were fertilized in vitro. Although polyspermy was a common feature (Miyamoto \& Chang, 1973b; Toyoda \& Chang, 1974a; Niwa \& Chang, 1974a), the proportion of eggs penetrated by more than one spermatozoon was not related to the age of the eggs before or after ovulation (Tables 4 and 8). There are indications that the process of fertilization and subsequent cleavage may be disturbed in the eggs penetrated by more than one spermatozoon (Table 8 ).

\section{ACKNOWLEDGMENTS}

This work was supported by grants (HD 03472, HD 03003) from NICHD and a grant from the Ford Foundation. One of us (M.C.C.) is a recipient of a Research Career Award (K6-HD 18, 334) from the National Institute of Child 
Health and Human Development. Thanks are due to Mrs Rose Bartke and Miss Dorothy Hunt for assistance.

\section{REFERENCES}

Austin, C. R. (1961) The Mammalian Egg. Blackwell Scientific Publications, Oxford.

Biggers, J. D. (1973) Oogenesis and ovum maturation. In The Regulation of Mammalian Reproduction, Ch. 20, pp. 273-283. Eds. S. J. Segal, R. Grozier, P. A. Corfman and P. G. Condliffe. C. C. Thomas, Springfield, Illinois.

Biggers, J. D., Whittingham, D. G. \& Donahue, R. P. (1967) The pattern of energy metabolism in the mouse oocyte and zygote. Proc. natn. Acad. Sci. U.S.A. 58, 560-567.

Blandau, R. J. (1952) The female factor in fertility and infertility. I. Effects of delayed fertilization on the development of the pronuclei in rat ova. Fert. Steril. 3, 349-365.

Blandau, R. J. \& Jordan, E. S. (1941) The effect of delayed fertilization on the development of the rat ovum. Am. J. Anat. 68, 275-289.

Brackett, B. G., Mills, J. A. \& Jertues, G. G. (1972) In vitro fertilization of rabbit ova recovered from ovarian follicles. Fert. Steril. 23, 898-909.

Chang, M. C. (1952) Fertilizability of rabbit ova and the effects of temperature in vitro on their subsequent fertilization and activation in vivo. F. exp. Zool. 121, 351-382.

Chang, M. C. (1955a) The maturation of rabbit oocytes in culture and their maturation, activation, fertilization and subsequent development in the Fallopian tubes. F. exp. Zool. 128, 379-406.

Crang, M. G. (1955b) Fertilization and normal development of follicular oocytes in the rabbit. Science, $\mathcal{N} . \Upsilon .121,867-869$.

Chano, M. G., Nrwa, K. \& Hunt, D. M. (1975) Fertilizing capacity of spermatozoa and fertilizable life of eggs from immature and mature rabbits and rats. In Aging Gametes. Ed. R. J. Blandau. Karger, New York (in press).

Cross, P. G. \& Brinster, R. L. (1970) In vitro development of mouse oocytes. Biol. Reprod. 3, $298-307$.

Donahue, R. P. (1968) Maturation of the mouse oocyte in vitro. I. Sequence and timing of nuclear progression. 7. exp. Zool. 169, 237-250.

Donahue, R. P. (1972) The relation of oocyte maturation to ovulation in mammals. In Oogenesis, Ch 22, pp. 413-438. Eds. J. D. Biggers and A. W. Schuetz. University Park Press, Baltimore.

Donahue, R. P. \& Stern, S. (1968) Follicular cell support of oocyte maturation: production of pyruvate in vitro. 7. Reprod. Fert. 17, 395-398.

Edwardos, R. G., Bavister, B. D. \& Steptoe, P. G. (1969) Early stages of fertilization in vitro of human oocytes matured in vitro. Nature, Lond. 221, 632-635.

Iwamatsu, T. \& Chang, M. C. (1971) Factors involved in the fertilization of mouse eggs in vitro. 7. Reprod. Fert. 26, 197-208.

Iwamatsu, T. \& Chang, M. C. (1972) Sperm penetration in vitro of mouse oocytes at various times during maturation. F. Reprod. Fert. 31, 237-247.

Kennedy, J. F. \& Donahue, R. P. (1969) Human oocytes: maturation in chemically defined media. Science, N.Y. 164, 1292-1293.

Mryamoto, H. \& Chang, M. C. (1973a) In vitro fertilization of rat eggs. Nature, Lond. 241, 50-52.

Mryamoto, H. \& Chano, M. C. (1973b) Fertilization of rat eggs in vitro. Biol. Reprod. 9, 384-393.

Monroy, A. \& Tyler, A. (1967) The activation of the eggs. In Fertilization, Vol. 1, pp. $369-412$. Eds. C. B. Metz and A. Monroy. Academic Press, New York.

Motı.x, J. \& Fulka, J. (1974) Fertilization and development in vivo of rabbit oocytes cultivated in vitro. J. Reprod. Fert. 40, 183-186.

Niwa, K. \& Chang, M. G. (1973) Fertilization in vitro of rat eggs as affected by the maturity of the females and the sperm concentration. 7. Reprod. Fert. 35, 577-580.

Niwa, K. \& Ghang, M. C. (1974a) Effects of sperm concentration on the capacitation of rat spermatozoa. F. exp. Zool. 189, 353-356.

Nrwa, K. \& Chang, M. C. (1974b) Optimal sperm concentration and minimal number of spermatozoa for fertilization in vitro of rat eggs. 7 . Reprod. Fert. $40,471-474$.

Niwa, K. \& Chang, M. C. (1974c) Various conditions for the fertilization of rat eggs in vitro. Biol. Reprod. 11, 463-469.

Noyes, R. W. (1952) Fertilization of follicular ova. Fert. Steril. 3, 1-12.

Pincus, G. \& Enzmann, E. V. (1935) The comparative behaviour of mammalian eggs in vitro and in vivo. 1. The activation of ovarian eggs. F. exp. Med. 62, 665-675.

Robertson, J. E. \& BAKer, R. D. (1969) Role of female sex steroids as possible regulators of oocyte maturation. A. Meeting, Soc. Study Reprod., Davis, Abstract No. 57, p. 29.

Schuetz, A. W. (1969) Oogenesis: processes and their regulation. Adv. Reprod. Physiol. 4, 99-148. 
Seitz, H. M., Rocha, G., Brackett, B. G. \& Mastroianni, L. (1971) Cleavage of human ova in vitro. Fert. Steril. 22, 255-262.

Soupart, P. \& Morgenstern, L. L. (1973) Human sperm capacitation and in vitro fertilization. Fert. Steril. 24, 462-478.

Thibault, G. (1973) In vitro maturation and fertilization of rabbit and cattle oocytes. In The Regulation of Mammalian Reproduction, Ch. 17, pp. 231-240. Eds. S. J. Segal, R. Crozier, P. A. Corfman and P. G. Condliffe. C. C. Thomas, Springfield, Illinois.

Toyoda, Y. \& Chang, M. C. (1974a) Fertilization of rat eggs in vitro by epididymal spermatozoa and the development of eggs following transfer. F. Reprod. Fert. 36, 9-22.

Toyoda, Y. \& Ghang, M. C. (1974b) Capacitation of epididymal spermatozoa in a medium with high $\mathrm{K} / \mathrm{Na}$ ratio and cyclic AMP for the fertilization of rat eggs in vitro. 7 . Reprod. Fert. 36, 125-134.

Yanagmachi, R. (1974) Maturation and fertilization in vitro of guinea-pig ovarian oocytes. F. Reprod. Fert. 38, 485-488.

YANAGIMAChI, R. \& Usul, N. (1972) The appearance and disappearance of factors involved in sperm chromatin decondensation in the hamster egg. F. Cell Biol. 55, 293a. 